\title{
Questionnaire for the Constitutional Law Experts of the Research Project 'The Role and Future of National Constitutions in European and Global Governance'
}

\author{
Anneli Albi
}

\begin{abstract}
The Questionnaire forms the basis for the twenty-nine national reports which were prepared as part of the research project 'The Role and Future of National Constitutions in European and Global Governance', funded by a five-year European Research Council grant. The Questionnaire contains three main parts, which address the following issues: (1) constitutional culture and constitutional amendments regarding EU membership; (2) constitutional/fundamental rights, the rule of law and constitutional adjudication regarding EU measures such as the Data Retention Directive, European Arrest Warrant and ESM Treaty; and (3) novel challenges that are increasingly highlighted in the wider context of global governance (i.e. beyond the classic international treaties that advance human rights, peace and environmental protection) in relation to democratic participation, judicial review and the rule of law. The different parts of the Questionnaire each start with a brief background outlining the specific constitutional issues or challenges encountered in some Member States, and subsequently invite the national constitutional law experts to explore these in relation to their respective countries. Whilst the mainstream English language European constitutional discourse has typically focused on autonomous EU constitutional law, the Questionnaire seeks to make
\end{abstract}

The Questionnaire was prepared as part of the research project 'The Role and Future of National Constitutions in European and Global Governance', funded by European Research Council grant No. 284316 (Project acronym: ConstEurGlobGov). The views are solely those of the Principal Investigator and cannot be attributed to the ERC or to the European Union. The Principal Investigator would like to thank Samo Bardutzky and linguistic editor Siiri Aulik for their helpful comments on the Questionnaire; however, the views and any errors are solely those of the author. Updates regarding the research project are available on the project website https:// research.kent.ac.uk/roc/.

All websites accessed 9 March 2016. The Questionnaire was prepared in January 2014, with some updates indicated in the text of the Questionnaire, along with some general editorial adjustments.

\footnotetext{
A. Albi (ه)

Law School, University of Kent, Canterbury, UK

e-mail: A.Albi@kent.ac.uk
}

(C) The Author(s) 2019

A. Albi and S. Bardutzky (eds.), National Constitutions in European

and Global Governance: Democracy, Rights, the Rule of Law,

https://doi.org/10.1007/978-94-6265-273-6_2 
available case law, doctrine and constitutional debates from the perspective of a multitude of national constitutional systems. It should be noted that the Questionnaire was prepared in 2013-14 when critical scholarly and public discussion about EU and transnational governance was generally rare; the Questionnaire does not address the recent illiberal trends.

\section{Project Summary and Main Objectives}

The European Research Council funded project 'The Role and Future of National Constitutions in European and Global Governance' revisits the role of national constitutions at a time when decision-making has increasingly shifted to the transnational level. The project has three objectives. First, it aims to carry out a comparative analysis on how constitutions reflect the transfer of powers from domestic to European and global institutions, and thus to what extent they provide legitimacy to the shift of the exercise of power to the transnational level and retain their social relevance. Secondly, while the discourse has come to associate national constitutions primarily with the protection of sovereignty, the project revisits constitutional values that have a continued importance in the contemporary globalising and pluralist legal setting, such as the protection of constitutional rights, the rule of law, legitimacy and democratic participation. The project explores constitutional court judgments from different Member States that tackle the protection of these rights and values in transnational judicial dialogues, e.g. in the field of data retention, arrest warrants and the Treaty Establishing the European Stability Mechanism (ESM Treaty). The project also assesses the responsiveness of the European Court of Justice (CJEU) with regard to the above rights and values, along with the standard of protection at supranational level. The third objective is to explore challenges that are increasingly highlighted in the context of global governance in relation to legitimacy, democratic control, accountability and the rule of law.

The Questionnaire that follows invited constitutional law experts ${ }^{1}$ to reflect on what has increasingly been described as the 'erosion' of constitutionalism, ${ }^{2}$ 'twilight of constitutionalism, ${ }^{3}$ 'de-constitutionalisation' at the domestic level ${ }^{4}$ or the 'hollowing out' of national constitutions ${ }^{5}$ and 'waning constitutionalism'. ${ }^{6}$ Others have noted a trend towards a thin, weak, procedural version of the rule of law, democratic control and judicial review ${ }^{7}$ in the context of Europeanisation and globalisation processes. Are such developments inevitable? If not, are the solutions primarily to be found in the

\footnotetext{
${ }^{1}$ For the constitutional law experts as well as the countries covered in the project, see the Introduction and the Preface in this edited volume.

${ }^{2}$ Grimm 2010, p. 4.

${ }^{3}$ Dobner and Loughlin 2010, p. xi.

${ }^{4}$ Peters 2006, p. 580.

${ }^{5}$ Peters 2005, p. 41; see further Introduction to Part 3 of the Questionnaire below.

${ }^{6}$ Rasmussen 2006, pp. 149-156.

${ }^{7}$ Harlow 2006, p. 195; Galera 2010b, p. 302.
} 
gradual constitutionalisation processes at the European and global level, as is the prevailing expectation in the discourse on European constitutional law and global constitutionalism? Might there also be a case for a more proactive engagement in upholding and enhancing constitutionalism at the national level? While the 'national' dimension has come to be somewhat tainted and neglected given its connotations of sovereignty, it warrants closer scrutiny, as the national courts, parliaments and other institutions provide the closest and, in practice, the most accessible means for individuals to shape and contest legal measures and hold public power accountable.

Whilst the Questionnaire is of a considerable length, a significant part of it provides an introductory context for the questions that follow, with a summary of a selection of relevant cases and commentary in different Member States. Experts were not expected to answer all questions at equal level of detail; they were invited to focus on issues that have been of particular relevance for the Member State in question. The reports form the basis for the Comparative Study that accompanies the present book with an analysis and synthesis of the research findings, as explained in the introductory chapter of this book.

It should be noted that the Questionnaire was prepared in 2013-14 when critical scholarly and public discussion about EU and transnational governance was, in general, rare and limited. The Questionnaire does not address the recent illiberal trends in different parts of Europe and beyond.

\section{Constitutional Amendments Regarding EU Membership}

Introduction The first objective is concerned with the role of constitutions internally within the state, and explores to what extent the content of the constitutions under examination remains credible and relevant given the realities of European governance. One key function of a constitution is to lay down the mechanisms governing the distribution and exercise of powers, and mutual checks and balances between the legislative, executive and judicial branches of power. In the context of European integration, the national mechanisms of decision-making have seen considerable alteration, given that more than half of the Member States' legislation today has its origins in EU law. Against this background, the key objective of the project will be to provide a comprehensive, comparative overview and analysis of EU-related amendments to national constitutions.

Additionally, the project has sought to test some of the hypotheses explored in the literature surrounding the question of why constitutions are/are not amended. On the one hand, among the benefits of amending constitutions in view of European integration, Bruno De Witte has noted the need to address the 'European deficit' in the national constitutions, due to the fact that the constitutions might be gradually becoming somewhat obsolete with regard to the realities in the exercise of powers. ${ }^{8}$

\footnotetext{
${ }^{8}$ De Witte 2001, p. 73.
} 
Based on a similar line of thought, Monica Claes and Anneli Albi have in separate writings called on states to take their own constitutions seriously. ${ }^{9}$ In Hjalte Rasmussen's view, the absence of EU-amendments in the Danish Constitution has resulted in a process of 'waning constitutionalism'. ${ }^{10}$ András Sajó has noted that the silence of a constitution on important issues 'will lessen the constitution's functionality and undermine its social relevance'. ${ }^{11}$ On the other hand, the choice not to amend may be due to reasons linked to constitutional culture, the degree of rigidity of the amendment procedures or other factors.

\subsection{Constitutional Culture}

Q 1.1.1 Constitutions have broadly been divided into two types. The first tend to have a legal character, with detailed rules and enforceability in courts; they have typically been adopted after the fall of an authoritarian regime or other cataclysmic event. The second type of constitutions tend to be more incrementally evolving, evolutionary, historical and political in nature. ${ }^{12}$ Is such a categorisation relevant to the Member State in question? If so, in which category does the national constitution fall? Has the national constitutional culture been influenced to a notable extent by constitutional traditions in another country or region?

Q 1.1.2 What is regarded as the rationale and role of the Constitution in the relevant Member State? Do the key elements of the rationale of the Constitution include (a) sovereignty and the organisation of the state; (b) limits to power through the protection of constitutional rights and liberties, the rule of law and the separation of powers with due checks and balances? If the Constitution is concerned with both of these areas and/or further areas, does the centre of gravity fall more into one area in particular?

\subsection{The Amendment of the Constitution in Relation to the European Union}

Q 1.2.1 How has the national constitution been adjusted in relation to EU membership? Please provide the timeline of the amendments (both in relation to initial membership as well as any subsequent amendments regarding the ratification of the Treaties or any other EU matters) along with the wording of the relevant provisions.

\footnotetext{
${ }^{9}$ Claes 2005, p. 124; Albi 2005, pp. 206-210.

${ }^{10}$ Rasmussen 2006, pp. 149-156.

${ }^{11}$ Sajó 2004, p. 427.

${ }^{12}$ For the two categories of constitutions, see e.g. Besselink 2006, pp. 113 et seq., and Albi 2005, pp. 22 et seq.
} 
Please include amendments where the EU was not explicitly mentioned but which implicitly concerned EU law.

Q 1.2.2 Please outline the constitutional amendment procedure. If different procedural options were available, please indicate which option was used for each EU-related amendment.

Q 1.2.3 If an amendment has been more recent (e.g. from 1995 onwards), please provide some further background on the aims of the amendment, the amendment process and the conceptual background behind the choice of wording. What drove the reform, which obstacles were encountered in the process and which key factors influenced the decisions on the scope and content of the amendment? To what extent was the advice of legal scholars and experts followed by political decision-makers?

Q 1.2.4 Have there been EU-related amendment proposals or related constitutional reform packages which have not materialised in practice? If so, please outline the aims and rationale of the proposals and the reasons why the amendments did not succeed. Are there currently any provisions which have been highlighted as in need of amendment in view of EU membership, or which the Expert considers to be in need of amendment?

\subsection{Conceptualising Sovereignty and the Limits to the Transfer of Powers}

Q 1.3.1 Regardless of whether the Constitution contains specific amendments, please summarise the rules that govern:

- the transfer or delegation of powers to the European Union;

- the supremacy and direct effect of EU law.

Q 1.3.2 How are the clauses on the transfer or delegation of sovereignty conceptualised in the relevant judgments of the constitutional court and the legal commentary? Would it be fair to say that an older interpretation of absolute sovereignty has been replaced by a modern, revised approach? For example, the Estonian Supreme Court recently made an explicit statement to this effect in the ESM case, stating that

... the Constitution does not require, despite the strict wording of the sovereignty clause, observation of absolute sovereignty. ... [M] embership of the EU and in international organisations has become a natural part of sovereignty in this day and age. ${ }^{13}$

\footnotetext{
${ }^{13}$ Supreme Court of Estonia, Case No. 3-4-1-6-12 on the ESM Treaty, English translation available at http://www.riigikohus.ee/?id=1347, para. 130 .
} 
Q 1.3.3 Are there nonetheless limits in the text of the Constitution, case law and/or constitutional commentary to the extent to which powers can be delegated to the EU? Have such limits changed over time? Can such limits be surpassed by recourse to a referendum?

Q 1.3.4 To what extent has the constitutional court or supreme court accepted the supremacy of EU law over the national constitution? Does the Constitution directly or indirectly proclaim the supremacy of the Constitution? If so, how have such provisions been interpreted in view of EU law? Would it be fair to say that the relevant court emphasises EU-friendly interpretation and generally seeks to avoid undermining EU law in practice?

\subsection{Democratic Control - National Parliaments and Referendums}

Q 1.4.1 Regardless of whether the Constitution contains specific amendments, please provide a summary of the rules that govern the participation of the national parliament in the EU decision-making processes. Are there any aspects in the parliamentary control in the relevant Member State that could be regarded as a best practice and which could be recommended more widely?

Q 1.4.2 Please provide a brief summary on referendums ${ }^{14}$ related to EU-amendments, ratification of EU treaties or other EU-related matters in the relevant Member State. Do the referendums on EU matters stand out, in any aspect, when one thinks of the role that direct democracy otherwise plays in the constitutional system of the Member State?

\subsection{The Reasons for, and the Role of, EU Amendments}

Q 1.5.1 If the Constitution has been amended to a considerable extent in relation to the EU, what was the rationale or the reasoning behind such amendment? Did any of the following considerations play a role: following best practices that have emerged in other countries; comparative influence of specific countries; constitutional culture; judicial decision(s), e.g. a finding by the constitutional court that the ratification of a Treaty was not possible without a constitutional amendment; following academic or expert advice; the quest to enhance the legitimacy of EU

\footnotetext{
${ }^{14}$ A linguistic remark should be made here: we will use the plural 'referendums' instead of 'referenda' throughout the book, as recommended by a number of leading publications in the field. Although the word 'referendum' can be derived from the Latin word 'referre', the word 'referendum' itself does not appear in the Latin language as a noun, and thus there is no need to use the Latin plural ending 'a'. See e.g. Suksi 1993, p. 10.
} 
membership; the need to take the Constitution seriously and to reflect the shift of power to the supranational level; public support; relative ease of the amendment procedure; anything else?

Q 1.5.2 If the Constitution has no EU-amendments or the EU-amendments are limited in their scope, please answer the following questions:

(a) What are the reasons behind such a disposition? Have any of the following considerations played a role: the degree of difficulty of the amendment procedure, possibly involving a referendum; constitutional culture; level of public support for the EU; anything else?

(b) As noted earlier, scholars have regarded constitutions that do not contain (significant) EU-amendments as being in the process of becoming somewhat obsolete with regard to the realities in the exercise of powers, and that such constitutions are experiencing reduced functionality and social relevance, or are not being taken seriously. The trend of 'waning constitutionalism' for example has been noted in Denmark. Have similar concerns been expressed in the relevant Member State? What is the Expert's view on this matter?

Q 1.5.3 How does the Expert see the role of national constitutions in the context where power is increasingly exercised at supranational and global level? Would it be important to amend the constitutions with regard to the impact of EU and international organisations on the exercise of powers and/or constitutional values? Please provide reasons. Experts are welcome to identify areas where amendment may be beneficial and/or to formulate tentative suggestions for amending the constitution(s).

\section{Constitutional Rights, the Rule of Law and EU Law}

Introduction The second objective is to explore the role of constitutions externally vis-à-vis European governance, in particular as regards upholding constitutional rights and substantive constitutional values in the supranational context.

It is common ground that in a wide range of areas, the EU has made a pioneering and far-reaching contribution to the advancement of rights, especially as regards the CJEU's case law on free movement rights, the rights of EU citizens and students, the right to non-discrimination, gender equality and the prohibition of age discrimination. Additionally, the EU Charter of Fundamental Rights (Charter) plays an important role, e.g. by introducing a range of modern rights. Inspired by advances in these rights as well as the important contribution that the EU has made to peace, security and relative prosperity, the scholarly narrative has traditionally focused on assessing the national constitutional and supreme courts from the perspective of whether they are co-operative, Euro-friendly and accept the supremacy of EU law, or whether they remain Eurosceptic and reluctant to relinquish power. This appears to stem from an implicit assumption that national constitutions primarily symbolise nationally-oriented and somewhat old-fashioned values such as sovereignty. 
However, in an increasing number of other areas, concerns have emerged about the standard of protection of constitutional rights, in particular in the Area of Freedom, Security and Justice. For example, a recent systematic analysis of the FIDE 2012 Congress Volume 3 reports on the national implementation of EU measures demonstrated that ' $[\mathrm{t}] \mathrm{he}$ uncritical focus on security has ... led ... to significant concerns regarding the impact of EU AFSJ law on the protection of fundamental rights'. ${ }^{15}$ Another author has noted that 'important values once recognised within the nation state are lost in the transition to the European level', and that especially pre-Lisbon, 'in the pursuit of substantive changes at the EU level even basic concepts such as fair trial and legality, which traditionally are recognised in national criminal law, seem to be forgotten' ${ }^{16}$ In a recent paper, the Principal Investigator of the present project explored a range of cases where the Grand Chamber of the European Court of Justice has prioritised loyal co-operation and effectiveness of EU law over constitutional rights. ${ }^{17}$ The paper went on to argue that constitutional rights have seen a degree of erosion as a result of the supremacy of EU law, and called for a recalibration of the law and discourse towards 'substantive co-operative constitutionalism' in the EU.

The present project seeks to carry out a more systematic research on the substantive constitutional concerns identified by constitutional courts and in constitutional commentary. The European constitutional law discourse has predominantly come to focus on the constitutional law of the European Union, with research focusing on the autonomous, self-referential rules developed by the CJEU rather than comparative constitutional standards. This Questionnaire seeks to bring together constitutional concerns which seem to have arisen in several Member States, but which may be scattered in commentary in national languages and thus may not always receive sufficient attention in the mainstream European discourse. It ought to be recalled that by invoking constitutional values, constitutional courts have historically served as catalysts for improvements in the EU's constitutional order, in particular the German Constitutional Court by virtue of its Solange I decision ${ }^{18}$ that prompted the CJEU to introduce fundamental rights protection. It is hoped that by clearly articulating substantive concerns that have emerged in several Member States with regard to constitutional rights and values, the project will make a contribution towards enhancing substantive constitutionalism in the European Union, with greater responsiveness on the part of the European Court of Justice, European and national institutions involved in EU decision-making processes as well as the scholarly discourse.

It may be worthy to note that while the above research perspective may enter into territory that many may regard as controversial, it is of real importance, since in practice only the CJEU can act as the final arbiter and, by virtue of the supremacy of EU law, it sets the standard for twenty-eight Member States. As Stephen Weatherill has famously noted, 'even the most minor piece of technical Community legislation

\footnotetext{
${ }^{15}$ Mitsilegas 2012, p. 141.

${ }^{16}$ Herlin-Karnell 2010, pp. 238 and 240.

17 Albi 2015a, pp. 151-185, and Albi 2015b, pp. 291-343. The two-part article includes most of the material and case studies contained in Part 2 of this Questionnaire.

${ }^{18}$ German Federal Constitutional Court, Internationale Handelsgesellschaft (Solange I) (1974) 2 CMLR, p. 549.
} 
ranks above the most cherished constitutional norm'. ${ }^{19}$ This is of considerable significance, as EU law is no longer restricted to primarily governing the single market, but extends post-Lisbon to wide-ranging areas of law.

The sections that follow will in most cases start with a brief background outlining the concerns about specific (constitutional) rights that have arisen in one or more Member States, and will then invite the Experts to consider whether these are isolated occurrences or whether similar concerns have emerged in their respective countries.

\subsection{The Position of Constitutional Rights and the Rule of Law in the Constitution}

Q 2.1.1 Please briefly outline to what extent (a) fundamental rights and (b) general principles of law (e.g. legal certainty and legitimate expectations, non-retroactivity, proportionality) are codified in the Constitution or have a constitutional rank. If there is a chapter on fundamental rights, is it comprehensive and detailed or relatively brief? To what extent are constitutional rights and general principles enforceable in courts?

Q 2.1.2 Is there a constitutional provision or a judicial ruling stipulating the conditions under which restrictions can be imposed on rights? For example, Art. 31(3) of the Polish Constitution provides as follows:

Any limitation upon the exercise of constitutional freedoms and rights may be imposed only by statute, and only when necessary in a democratic state for the protection of its security or public order, or to protect the natural environment, health or public morals, or the freedoms and rights of other persons. Such limitations shall not violate the essence of freedoms and rights. ${ }^{20}$

Q 2.1.3 Is there a constitutional category equivalent or similar to the rule of law (or Rechtsstaat; Etat de droit) mentioned in the text of the Constitution of the relevant Member State? How is the concept of the rule of law conceptualised in the case law and legal commentary? What are the key elements of the concept? To what extent is the principle of the rule of law justiciable? Is the rule of law frequently used as an argument by applicants (in contesting legal acts) and courts (in exercising judicial review)?

It has been noted that access to courts, a right that has come to be explicitly recognised in the national constitutions, is of particular importance to the rule of law in the convergent principles of constitutional law in Europe. ${ }^{21}$ Please comment on the extent to which access to courts and the right to judicial review are

\footnotetext{
${ }^{19}$ Weatherill 1995, p. 106.

${ }^{20}$ Translations from the unofficial translation of the Polish Constitution, http://www.sejm.gov.pl/ prawo/konst/angielski/kon1.htm.

${ }^{21}$ Galera 2010a, p. 277, referring to Storskrubb and Ziller 2007, pp. 180 et seq.
} 
constitutionally entrenched and/or regarded as a core element of the rule of law in the relevant Member State.

To what extent are the following principles regarded as core elements of the rule of law in the relevant Member State:

- The rule that only published laws can be valid;

- Legal certainty and non-retroactivity;

- The rule that the imposition of obligations, administrative charges or penalties and criminal punishments is only permissible on the basis of a parliamentary statute, and that sanctions cannot be applied retroactively, through inference from objectives by virtue of teleological reasoning or by analogy.

\subsection{The Balancing of Fundamental Rights and Economic Freedoms in EU Law}

Prior to the Omega ${ }^{22}$ and Schmidberger ${ }^{23}$ judgments in 2003-2004, the European Court of Justice by and large gave priority to the fundamental freedoms, i.e. economic free movement rights, in cases where these clashed with more classic constitutional and/or fundamental rights. Although in Omega and Schmidberger priority was given to the right to human dignity and the freedom of expression respectively, concerns continue to be expressed that classic fundamental rights have in the context of EU law become 'restrictions' to economic free movement rights, with the canon of interpretation being that exceptions to free movement rights must be interpreted strictly.

In the FIDE 2012 Congress Volume 1 reports on the protection of fundamental rights post-Lisbon, the national reports of Cyprus, Bulgaria, the Czech Republic, Ireland and Germany note that the national courts typically prioritise classic fundamental rights over economic freedoms, and that such an approach has changed, or is likely to change, in matters that fall within the scope of EU law, given the CJEU's different approach to balancing. ${ }^{24}$ The Irish Report in particular notes that during the referendums on the Lisbon Treaty, cases such as Laval and Viking ${ }^{25}$ prompted concerns that the EU prioritised economic liberties over traditional human rights, and that the CJEU imposed significant limitations on the right of workers to take collective action where the exercise of that right interfered with the

\footnotetext{
22 Case C-36/02 Omega [2004] ECR I-09609.

${ }^{23}$ Case C-112/00 Schmidberger [2003] ECR I-05659.

${ }^{24}$ See the relevant reports in Laffranque 2012a; see also 'Questionnaire' by Besselink 2012, pp. 8 9 in the same volume.

${ }^{25}$ Case C-341/05 Laval [2007] ECR I-11767 and Case C-438/05 The International Transport Workers' Federation and The Finnish Seamen's Union [2007] ECR I-10779.
} 
freedom of establishment and freedom to provide services. ${ }^{26}$ The issues raised by this line of cases regarding collective action have also led to significant scholarly and political concern elsewhere.

Q 2.2.1 Does the balancing of fundamental rights and economic free movement rights raise constitutional issues in the relevant Member State and in the Expert's view? Have the national courts adjusted their balancing to match the CJEU's approach? If so, what has been seen as the objective of, or justification for, the relevant change?

\subsection{Constitutional Rights, the European Arrest Warrant and EU Criminal Law}

Whereas in the past the balancing of rights primarily concerned the sphere of the single market, more recent developments in the Area of Freedom, Security and Justice mean that classic personal liberties have increasingly been affected by EU rules. The following sections will focus in particular on constitutional rights in the context of the European Arrest Warrant (EAW). Between 2005-2011, EU Member States issued a total of 78,785 EAW requests, with 19,841 requests resulting in the effective surrender of the person, according to data compiled by a report by the Centre for European Policy Studies (CEPS). ${ }^{27}$

\subsubsection{The Presumption of Innocence}

By virtue of the EAW Framework Decision, ${ }^{28}$ extradition has been rendered speedy and near-automatic in the EU Member States. A court that receives an extradition request from another Member State must automatically authorise extradition, with minimum formality and no consideration of evidence.

The impact of the above rule on the presumption of innocence and on the principles of the rule of law and proportionality has been queried by Judge Broß in his dissenting opinion to the German Constitutional Court's European Arrest Warrant judgment. ${ }^{29} \mathrm{He}$ notes that the presumption of innocence protects the person charged from the disadvantages that are equivalent to a verdict of guilty, where such disadvantages have not been preceded by proceedings where evidence

\footnotetext{
${ }^{26}$ Kiernan et al. 2012, p. 539.

${ }^{27}$ Carrera et al. 2013, p. 16.

${ }^{28}$ Council Framework Decision of 13 June 2002 on the European arrest warrant and the surrender procedures between Member States (2002/584/JHA), [2002] OJ L 190/1.

${ }^{29}$ BVerfG, case 2 BvR 2236/04, European Arrest Warrant I, judgment of 18 July 2005, BVerfGE 113, 273, 304 et seq. http://www.bundesverfassungsgericht.de/SharedDocs/Entscheidungen/EN/ 2005/07/rs20050718_2bvr223604en.html, paras. 144-153.
} 
of guilt has been provided in compliance with the code of procedure. He holds that in the EAW system, which does not allow for examination of the circumstances pertaining to the alleged offence or crime, prosecuted persons are treated as guilty in the context of the extradition proceedings, which is contrary to the rule of law.

Q 2.3.1.1 Have concerns with regard to the presumption of innocence arisen in the relevant Member State in this context? How have the courts and legal commentary approached the presumption of innocence in the context of the European Arrest Warrant? Please indicate the constitutional provisions which have been affected, as articulated by the courts, legal commentary and/or in the Expert's view. On the basis of national case law and in the Expert's view, can a conclusion be drawn that the principle of presumption of innocence can no longer fully be granted the same level of protection as prior to the entry into force of the EAW Framework Decision? If so, what is regarded as the objective of, or justification for, limiting this right?

Q 2.3.1.2 Is the prevailing practice for judges in the relevant Member State to rubber-stamp extradition requests, or to grant a hearing and/or carry out some form of preliminary judicial review? Do the courts review evidence prior to extradition where the person claims his or her innocence? If so, on how many occasions has extradition been refused on this ground?

\subsubsection{Nullum Crimen, Nulla Poena Sine Lege}

A central element of the EAW Framework Decision is that the rule of double criminality is abolished for 32 crimes, and thus a person must be extradited regardless of whether the act in question constitutes a crime in domestic law. Concerns have been expressed that each Member State is effectively accepting the criminal laws of all other Member States of the EU, without a clear picture of what those laws might be. ${ }^{30}$ A further issue that has provided grounds for concern is the wide, open-ended wording in the list of '32 types of offences'; it has been commented that these are merely 'types' and not well-defined offences (e.g. 'racism and xenophobia'), and that some offences are susceptible to politicisation (e.g. 'terrorism', 'participation in a criminal organisation' and 'racism and xenophobia'). ${ }^{31}$ There have also been concerns about different penalties for the same crime in different Member States.

The nulla poena sine lege rule led the Belgian Constitutional Court to request a preliminary ruling from the CJEU on the legality of the European Arrest Warrant Framework Decision. ${ }^{32}$ This was prompted by a concern from an association of defence lawyers that the abolition of double criminality was in breach of the principle of legality in criminal matters. Under national constitutions, criminal

\footnotetext{
${ }^{30}$ Alegre and Leaf 2004, p. 208.

31 Sanger 2010, pp. 21-22.

32 Case C-303/05 Advocaten voor de Wereld [2007] ECR I-03633.
} 
legislation must satisfy the conditions of precision, clarity and predictability, allowing each person to know whether an act constitutes an offence.

The concern about nulla poena sine lege was echoed in a more limited way by the German Constitutional Court, ${ }^{33}$ which found that the issue of retroactive amendment of substantive criminal law would arise in cases where an individual is extradited to another Member State for an act that does not have a significant connecting factor to the requesting state and that was not punishable in Germany when the act was committed. The Court explained the threat to the rule of law as follows:

The principle according to which an offence may only be punished if punishability was legally determined before the offence was committed is a special guarantee under the rule of law of the confidence in the reliability of the legal system, which is to provide clear orientation on what is punishable and what is not. Without such reliable orientation, individual freedom cannot develop: Whoever must expect an unpredictable retroactive amendment of criminal-law provisions will no longer be able to exercise his or her freedom of action with the necessary security, and will lose his or her position as an autonomous individual in one of the areas that are most sensitive as concerns fundamental rights.

According to the FIDE 2012 Congress Volume 3 reports, the legality of the abolition of dual criminality has also been contested in Greece, Spain, Finland and Denmark, especially in relation to offences that have not been harmonised in the EU. ${ }^{34}$ In the view of the Portuguese rapporteurs, abolition of dual criminality may foster a repressive 'European criminal space'. ${ }^{35}$ In the Czech Republic, the breach of the legality principle has also been contested with regard to other mutual recognition instruments, such as confiscation and freezing orders.

Q 2.3.2.1 How have the above constitutional issues been approached in the relevant Member State's case law and legal commentary? Please outline the constitutional provisions affected, either as articulated by the courts, legal commentary and/or in the Expert's view. On the basis of national case law and in the Expert's view, can a conclusion be drawn that the principle of nullum crimen sine lege, nulla poena sine lege can no longer fully be granted the same level of protection as prior to the entry into force of the EAW Framework Decision? If so, what is regarded as the objective of, or justification for, limiting this principle?

\subsubsection{Fair Trial and In Absentia Judgments}

The EAW rules on in absentia judgments, as amended in 2009, prompted a preliminary ruling request by the Spanish Constitutional Court in Melloni. ${ }^{36}$ In the past, the Spanish Constitutional Court had on numerous occasions prohibited

\footnotetext{
33 Judgment of 18.7.2005, 2 BvR 2236/04, supra n. 29, para. 99.

${ }^{34}$ See Mitsilegas 2012 and country reports in the same volume (Laffranque 2012b).

${ }^{35}$ Vitorino and Leandro Vasconcelos 2012, p. 540.

${ }^{36}$ Case C-399/11 Melloni [2013] ECLI:EU:C:2013:107.
} 
extradition to serve a severe sentence imposed in the absence of the requested person, where no possibility of a retrial was available. This included circumstances where the person had been represented in another Member State by a lawyer, without being present at the proceedings.

In the Spanish Constitutional Court's view, changing the above practice so as to allow extradition in such circumstances would breach the constitutional right to a fair trial and the rights of defence. The first paragraph of Art. 24 of the Spanish Constitution provides that '[e]veryone has the right to obtain effective protection from judges and the courts in the exercise of his rights and legitimate interests, and in no case may there be a denial of defence'. The Court noted that in its case law,

\begin{abstract}
the right to participate in the oral procedure and to mount one's own defence forms part of the nucleus of the rights of defence which must be regarded as essential under Article 24 of the Constitution. ... Only by means of physical presence at the trial can rejection of or acquiescence to the accusation be manifested, and the declaration by the accused can become part of his defence, witnesses can be questioned and examined, the defence conducted with specialised assistance from a lawyer can be coordinated and, finally, the right to the last word can be exercised... . ${ }^{37}$
\end{abstract}

According to the Spanish Constitutional Court, extradition without respect for the above 'undermines the essence of due process in a way which affects human dignity'. In the preliminary ruling question, the Constitutional Court asked the European Court of Justice whether it could no longer refuse the execution of an arrest warrant in the above circumstances. The Grand Chamber of the CJEU confirmed that the previous level of protection granted to Art. 24 of the Spanish Constitution was no longer available.

Q 2.3.3.1 Have in absentia judgments raised constitutional issues in the relevant Member State? Please outline the relevant constitutional provisions. Do in absentia judgments raise constitutional issues in the Expert's opinion? Have the national courts had to revisit the standard of protection in cases involving in absentia judgments in the context of the EAW Framework Decision? If so, what is regarded as the objective or justification?

\title{
2.3.4 The Right to a Fair Trial - Practical Challenges Regarding a Trial Abroad
}

The German Constitutional Court has explained the importance of the state's responsibility for its own citizens and why citizens ought not to be removed against their will from the legal system with which they are familiar. According to the Court, ' $[\mathrm{t}] \mathrm{o}$ the extent that they reside in the state territory, all citizens are supposed to be protected from the insecurities connected with being sentenced in a legal

\footnotetext{
${ }^{37}$ C-399/11-1, Order of 9 June 2011 of the Spanish Constitutional Tribunal (Plenary Formation), in the matter of Recurso de Amparo (petition for constitutional protection) lodged by Stefano Melloni, on file with the author.
} 
system that is unknown to them under circumstances that are inscrutable to them'. ${ }^{38}$ The Court further noted that for the prosecuted person,

transfer to another Member State's legal system, even though it has been brought closer by European integration, not only means discrimination under procedural law, which can consist in language obstacles, cultural differences and different procedural law and possibilities of defence. Such transfer ultimately ties the prosecuted person to a substantive criminal law in respect of which no democratic means had existed for him or her to participate in its creation, which he or she - unlike German criminal law - does not need to know and which in many cases due to a lack of familiarity with the respective national context, does not permit him or her as a layperson a sufficiently secure comparative evaluation. ${ }^{39}$

Fair Trials International has noted the following: 'Too often we encounter people imprisoned for months or years before their trial even starts, who have no idea of their rights, no comprehension of the local legal system and no legal aid to help them pay for a lawyer or interpreter. ${ }^{40}$ In his dissenting opinion to a decision of the Czech Constitutional Court, Judge Balik has expressed concern about the feasibility of defending oneself in a language other than one's mother tongue, in addition to other difficulties which may arise, such as the high cost of flights for family members, which may be more than the average monthly salary in some countries. ${ }^{41}$

Q 2.3.4.1 Does the relevant Member State provide assistance to its extradited citizens or residents, e.g. by way of travel expenses, assistance with quality translation and legal aid? (Note that this question does not concern the recently adopted EU Directives regarding the respect of the relevant rights by the state to which the person has been extradited, but by the state of citizenship/main residence). In the United Kingdom, a parliamentary hearing was granted to individuals who had been extradited but were subsequently found innocent. Please outline any similar practices by public institutions in the relevant Member State.

Is there a public or non-governmental organisation that provides assistance to persons extradited from the relevant Member State? If so, what assistance do they provide? In the case of a non-governmental body, how are the activities of the NGO (predominantly) funded?

Would the Expert support a recommendation to introduce a publicly funded state or non-governmental body to provide assistance to residents who are involved in trials abroad?

Q 2.3.4.2 With reference to the statistical data on extraditions in 2005-2011, based on the CEPS report mentioned in Sect. 2.3 above, it would be helpful if the Experts could seek to determine how many of the extradited individuals were subsequently found innocent. How does the percentage compare to those found innocent in the course of domestic trials? If an individual was subsequently found innocent, what

\footnotetext{
38 Judgment of 18.7.2005, 2 BvR 2236/04, supra n. 29, para. 66.

39 Judgment of 18.7.2005, 2 BvR 2236/04, supra n. 29, para. 86.

${ }^{40}$ http://www.fairtrials.net/get-involved/.

${ }^{41}$ Dissenting opinion by Judge Balík to Case No. Pl. ÚS 66/04, http://www.concourt.cz.
} 
compensation was provided, especially given the cost of travel and the stay abroad for the suspect and his or her family?

If possible, please provide examples of individuals who have been extradited but have subsequently been found innocent, e.g. from media coverage.

\subsubsection{The Right to Effective Judicial Protection: The Principle of Mutual Recognition in EU Criminal Law and Abolition of the Exequatur in Civil and Commercial Matters}

One of the Czech rapporteurs for the FIDE 2012 Congress has commented as follows:

The EU mutual recognition instruments, be it European arrest warrant, European evidence warrant, freezing order, confiscation order, mutual recognition of financial penalties or sentencing judgments or probations, present great challenges for the legal systems of Member States, including the Czech Republic. ... One of the most significant challenges is the shift of paradigm, whereby executing authorities are supposed to recognise and execute foreign judgments and other judicial decisions (in case of financial penalties, the respective decisions might also come from administrative authorities) almost automatically, while trusting that underlying foreign procedures and decisions observed fundamental rights and fulfilled particularly fair trial requirements. The mutual recognition instruments help to expand the operation of national law throughout the EU and might clash with domestic constitutional requirements as regards the substantive legality principle, principle of legal certainty or prerogatives of its own citizens or fundamental rights requirements generally. ${ }^{42}$

In Estonia, an attorney has called for a parliamentary debate on constitutional rights with regard to the abolition of the exequatur in civil matters in the aftermath of the following case. Mr. Piirsoo, a truck driver, discovered in 2009 that his bank account was 430,000 EUR in debt, with a further 192,000 EUR added at a later stage by way of interest accrued. The Estonian customs authorities had automatically executed a customs tax demand notice issued by the German authorities. ${ }^{43}$ Earning 700 EUR a month, the driver had little choice but to declare bankruptcy. He had been acquitted nine years earlier in Germany of cigarette smuggling charges, but Germany nonetheless demanded payment of customs tax. When his attorney sought to contest the demand notice in Germany, it emerged that the deadline for submitting the application had passed in 2000, when Mr. Piirsoo was detained in a German prison.

The attorney in the case, Mr. Siim Roode, called for a parliamentary debate to highlight the need for Estonian state authorities to provide assistance to citizens. He posed the question of whether it is compatible with the Constitution to enforce foreign administrative acts without the possibility of judicial review in a local court,

\footnotetext{
42 Švarc 2012, p. 269.

${ }^{43}$ Henno, E. (2009, November 4) Saksamaa nõuab eestlaselt miljoneid kroone (Germany demands millions of kroons from an Estonian). Postimees. http://www.postimees.ee/183910/ saksamaa-nouab-eestlaselt-miljoneid-kroone.
} 
a practice that is required by the relevant EU measures under the principle of mutual recognition. ${ }^{44}$ The attorney recalled that the right to judicial protection is a fundamental right, which must be exercisable in a manner that is not overly onerous for the individual. ${ }^{45}$ The right to judicial protection must be accessible within a reasonable time and at a reasonable cost. According to the attorney, the possibility to request judicial review of an act of a foreign authority in a foreign country does not meet these criteria, and is not within the reach of natural persons, i.e. individuals. ${ }^{46}$

Q 2.3.5.1 Have similar constitutional issues arisen with regard to mutual recognition in the relevant Member State? How has the move to mutual recognition been reconciled with the requirements of the rule of law and the right to effective judicial protection in the case law and legal commentary? On the basis of case law and in the Expert's view, can a conclusion be drawn that the principle of effective judicial protection and the rule of law can no longer fully be granted the same level of protection as prior to the introduction of the mutual recognition rule in criminal law and the abolition of the exequatur in civil and commercial matters? What is regarded as the objective of, or justification for, limiting the rights related to judicial protection?

Q 2.3.5.2 Has there been debate about the suitability of transposing mutual recognition from internal market matters, such as alcohol content in blackcurrant liqueurs as in Cassis de Dijon, ${ }^{47}$ to criminal law and civil and commercial disputes? What is the Expert's view?

Q 2.3.5.3 Has any concern been expressed in the relevant Member State about a change in the role of courts, from providing judicial protection against unwarranted measures by the authorities, to becoming actors of loyal co-operation, efficiency and trust? What is the Expert's view on this matter? Is there reason to be concerned?

Q 2.3.5.4 In the United Kingdom, NGOs have called for the introduction of a proportionality test prior to extradition, due to extradition requests for a wide range of 'trivial' offences. ${ }^{48}$ In the relevant Member State, have there been any calls for reintroducing some form of judicial review in the country of residence of the individual affected?

Would the Expert support a recommendation to reinstate some form of judicial review in the context of extradition, e.g. to ensure that there is sufficient evidence against the individual, that the offence is sufficiently serious, and that there is a sufficient link between the offence and the country to which the individual is

\footnotetext{
${ }^{44}$ Ibid.

${ }^{45}$ Further comment by S. Roode on the case by e-mail, on file with the author. ${ }^{46}$ Ibid.

${ }^{47}$ Case C-120/78 Rewe v. Bundesmonopolverwaltung für Branntwein [1979] ECR 00649.

${ }^{48}$ See (2008, October 20) Door Thief, Piglet Rustler, Pudding Snatcher: British Courts Despair at Extradition Requests. The Guardian; Wade, A. (2009, August 13) Extradited for 'stealing' a mobile phone. Times Online. http://www.thetimes.co.uk/tto/law/article2214808.ece.
} 
extradited? Would the Expert support reinstatement of judicial review by a local court in civil and commercial matters?

\title{
2.3.6 Constitutional Rights Regarding Other Aspects of EU Criminal Law
}

Please use this section if any further constitutional issues have arisen in the case law and/or legal commentary, and/or in the Expert's view, in relation to European Union criminal law in the relevant Member State.

German Government's pleading in the $E A W$ case to revise the concept of the rule of law (addition to the Questionnaire on 8 July 2014) Given the project's focus on the rule of law, the Experts may find it of interest to note the German Government's pleading in the EAW case to move from national requirements for the principles of the rule of law to a 'constitutional tradition that connects Europe and North America'. In para. 39 of the German Constitutional Court's EAW case, the Government's submission is summarised as follows:

\begin{abstract}
The protection of German citizens from extradition can be restricted by a formal Act of Parliament. The European Arrest Warrant Act is such an Act. Pursuant to this Act, extradition can only be ordered if the 'principles of the rule of law' are adhered to. It results from the wording as well as from the objective of the relevant provision in the constitution that these principles cannot be equated with the nationally applicable requirements that result from the Basic Law's principle of the rule of law. On the other hand, the provision makes reference to more than a minimum standard under public international law. Instead, it establishes a reference to a 'constitutional tradition that connects Europe and North America' with the core standards of due process in criminal proceedings that results from this tradition. The legislature can assume that these standards are complied with in the European Union and its Member States because they are already a prerequisite for Union membership. In the individual case, a prosecuted person can invoke the ordre public in $\S 73$ sentence 2 of the Law on International Judicial Assistance in Criminal Matters, which corresponds to the all-European ordre public under Article 6 of the Treaty on European Union.
\end{abstract}

In the sections regarding the rule of law, it might be of interest to report on whether there have been similar calls to change the concept of the rule of law in other Member States, and whether the Experts have views on the desirability of such a change.

\subsection{The EU Data Retention Directive}

The EU Data Retention Directive $2006 / 24^{49}$ has seen constitutional challenges in a number of Member States. While the Grand Chamber of the CJEU had previously

\footnotetext{
${ }^{49}$ Directive 2006/24/EC of the European Parliament and of the Council of 15 March 2006 on the retention of data generated or processed in connection with the provision of publicly available
} 
confirmed the legality of the Directive, ${ }^{50}$ two new cases, from Austria and Ireland, were pending at the CJEU at the time of preparing this Questionnaire and eventually led to the annulment of the Directive. ${ }^{51}$

In Germany, an action was brought before the Constitutional Court by more than 34,000 citizens. The German Constitutional Court found that the national implementing law contravened Germany's Constitution, and especially the right to privacy and proportionality. ${ }^{52}$ The Court noted that the storage of data envisioned constitutes a particularly serious encroachment with an effect broader than anything in the legal system to date. It allows third persons to obtain detailed information on a person's social or political affiliations and personal preferences, inclinations and weaknesses, making it possible to create personality profiles of virtually all citizens and to track their movements. According to the Court, it is part of Germany's constitutional identity that the citizens' enjoyment of freedom may not be totally recorded and registered.

The Romanian Constitutional Court has noted the national implementing act's 'large applicability - practically to all physical and legal persons.${ }^{53}$ According to the Romanian Constitutional Court, this is likely to overturn the presumption of innocence, transforming a priori all users of electronic communication services into suspects, and to breach the right to private life, secrecy of correspondence and freedom of expression.

Q 2.4.1 In April 2014, the Court of Justice annulled the Data Retention Directive. The annulment was based on the disproportionality of the interference as regards the lack of safeguards on access and time limits; however, the Court found the underlying requirement of blanket data retention justified in view of the overriding objective of general interest (security). Advocate General Cruz Villalon had recommended suspension of the invalidity until the Directive was revised. We would welcome the Expert's reflection on the following matters:

- Did the implementation of the Data Retention Directive raise constitutional issues in the relevant Member State? Please outline the constitutional provisions affected. How did the courts or other bodies reconcile the Directive's requirements with constitutional rights during the period of 2006-2014 prior to annulment?

\footnotetext{
electronic communications services or of public communications networks and amending Directive 2002/58/EC, [2006] OJ L 105/54.

${ }^{50}$ Case C-301/06 Ireland v. Parliament and Council [2009] ECR I-00593.

${ }^{51}$ Joined cases C-293/12 and C-594/12 Digital Rights Ireland and Seitlinger and Others [2014] ECLI:EU:C:2014:238.

${ }^{52}$ German Federal Constitutional Court, Judgment of 02.03.2010, 1 BvR 256/08, 1 BvR 263/08, 1 BvR 586/08. For an English summary, see www.bundesverfassungsgericht.de/en/press/bvg10011en.html.

${ }^{53}$ Romanian Constitutional Court, Decision No. 12581 of 08.10.2009, English translation available at www.legi-internet.ro/fileadmin/editor_folder/pdf/decision-constitutional-court-romaniadata-retention.pdf.
} 
- If the national implementing act was adjudicated by the national constitutional or supreme court without a preliminary reference to the CJEU, was the CJEU's finding of the legality in the 2009 Ireland $v$. Council case regarded as having settled the matter of the legality of the Directive (and thus a reason why no further challenge to the validity was sent to the CJEU)?

- On the basis of previous case law and in the Expert's view, can a conclusion be drawn that in the domestic context, without the constraints of the EU legal order, there would have been a high degree of probability that a measure equivalent to the Data Retention Directive would not have been found compatible with the Constitution by the constitutional court? Would the national constitutional court or supreme court, in the context of national constitutional law without the constraints of the EU legal order, likely have found the underlying rule of blanket data retention compatible with the Constitution (rather than focusing on the proportionality of the rules on safeguards for access and time limits)?

- What was the consequence of the annulment by the CJEU for the relevant national implementing act? Has it been invalidated or will it continue to exist? Can it be said that the Directive may have established a new baseline for the national system in terms of the acceptability of blanket data retention?

\subsection{Unpublished or Secret Legislation}

In the Heinrich case ${ }^{54}$ an Austrian court queried the legality of the adoption of secret legislation by EU institutions. The Austrian court noted that keeping secret the rules of conduct with which individuals are required to comply constituted such a severe impairment of the most elementary principles of the rule of law that such regulations were legally non-existent and hence could not be binding. The Grand Chamber of the Court of Justice of the European Union decided that the secret EU regulation, while it could not impose obligations on individuals, remained valid law.

The CJEU's approach followed its earlier case law in relation to EU measures that had not been translated into and published in the languages of the new Member States in time for accession. In that context, the Polish, Czech and Estonian courts revisited their previous, more stringent approach whereby unpublished measures had been declared invalid, noting that the CJEU's approach in the Skoma-Lux case $^{55}$ had been more lenient. ${ }^{56}$

Q 2.5.1 Has the question of the constitutionality of unpublished or secret measures arisen in the relevant Member State? How do the Heinrich and Skoma-Lux rulings compare to the national case law on the validity of such measures? If there has been

\footnotetext{
${ }^{54}$ Case C-345/06 Heinrich [2009] ECR I-01659.

${ }^{55}$ C-161/06 Skoma-Lux [2007] ECR I-10841, para. 37.

${ }^{56}$ See in more detail Bobek 2009, pp. 43 et seq., and Albi 2011, Sect. 3.1.
} 
no national case law dealing with similar issues, we would welcome the Expert's view on whether the existence of unpublished or secret measures would be deemed valid under the Constitution of the relevant Member State.

\subsection{Rights and General Principles of Law in the Context of Market Regulation: Property Rights, Legal Certainty, Non-retroactivity and Proportionality}

In the context of the single market, German judges expressed concern during the so-called 'Banana Saga' in the 1990s that the CJEU was giving the EU institutions 'a carte blanche' and reducing judicial control to a minimum. ${ }^{57}$ British scholars have noted the hands-off approach in matters of economic regulation, where the EU Courts allow the EU institutions to enjoy considerable discretion, resulting in 'the threshold of illegality being placed very high'. 58

This section seeks to explore the impact of EU law on the national standard of protection of property rights, legal certainty, non-retroactivity and proportionality in the adjudication of the validity of EU measures or measures implementing EU law in the field of market regulation.

This section has been prompted by a recent series of cases, described as the 'Sugar Saga' in several new Member States. ${ }^{59}$ By way of a brief summary, courts in several new Member States reduced the level of protection of a range of constitutional rights in order to ensure the supremacy of EU law in the context of adjusting the quantities of agricultural products held by undertakings in view of the transition to the Common Agricultural Policy. These rights included the protection of private property and the rule that expropriation of property is only allowed in exceptional cases for public purposes, on the basis of a specific parliamentary statute and in return for compensation. The protection of property is accompanied by the constitutional rule that taxes, fines or pecuniary obligations can only be imposed under a parliamentary statute, with any grounds being interpreted narrowly and no retroactivity allowed. This is further protected by the principles of legal certainty and legitimate expectations. In the process, the Polish and Cypriot governments brought actions to the EU General Court, arguing that implementation of the EU requirement to impose fines on undertakings that had purchased sugar before EU accession was not possible without breaching the above rights in a disproportionate manner.

All of the challenges were rejected by the EU Courts as part of the practice of interpreting the general principles of EU law in a way that gives a wide margin of

\footnotetext{
${ }^{57}$ Everling 1996, p. 419.

${ }^{58}$ For relevant case law, see Chalmers et al. 2006, pp. 436-437.

${ }^{59}$ See Albi 2010, pp. 791-829.
} 
discretion to the EU institutions. As regards the right to property, the EU Courts had previously found no violations by EU measures until Kadi, ${ }^{60}$ which pertained to UN measures. ${ }^{61}$ Indeed, a judge from the European Court of Human Rights (ECtHR) had expressed concern as to whether the protection granted by the EU Courts to property rights under Art. 1 of Protocol 1 of the European Convention on Human Rights (ECHR) corresponded to that granted by the ECtHR. ${ }^{62}$ As regards the principle of legitimate expectations, the overwhelming majority of claims have been rejected by the Court of Justice: one can rely on this principle only if specific assurances have been given by the EU institutions. ${ }^{63}$ In the case of undertakings, the EU Courts expect a prudent and well-informed trader to foresee changes in the law. This interpretation is narrower than that used by Central and Eastern European constitutional courts before the 'Sugar Saga': in their previous case law, it was held that the imposition of obligations required a lead-in period, and laws that retroactively established obligations or pecuniary charges on individuals were prohibited and declared unconstitutional.

The 'Sugar Saga' additionally involved a case where both EU Courts upheld the legality of a 45 million EUR fine that had been imposed by the European Commission on Estonia for sugar that had been held by households, i.e. private individuals. The fine had been imposed on the basis of a requirement that was first written down in the same instrument that imposed the 45 million EUR fine, adopted one year after EU accession. ${ }^{64}$ The fine was upheld despite the General Court's acknowledgement that there had been no textual basis in EU law for the alleged requirement to eliminate private household sugar and, furthermore, despite the Court's recognition that, in practice, it would have been impossible to require private households to dispose of their sugar. The fine was upheld on the basis of teleological interpretation and the principle of effectiveness of EU law.

The Czech Constitutional Court carried out a comparison of domestic and EU standards of protection of the principles of legitimate expectations, legal certainty, non-retroactivity and non-discrimination, the right to undisturbed engagement in economic activity and property rights, in a decision concerning sugar production quotas delivered on 8 March $2006 .{ }^{65}$ It noted with regard to each right the high margin of discretion left by the CJEU to the Member States when implementing the Common Agricultural Policy. Indeed, as regards the principle of proportionality, it noted the 'highly deferential standard', and that fundamental rights 'may be subject

\footnotetext{
${ }^{60}$ Joined cases C-402/05 P and C-415/05 P Kadi and Al Barakaat International Foundation v. Council and Commission [2008] ECR I-06351.

${ }^{61}$ Tridimas 2006, p. 315.

${ }^{62}$ Concurring Opinion of Judge Ress in Bosphorus Hava Yollarl Turizm ve Ticaret Anonim Sirketi v. Ireland [GC], no. 45036/98, ECHR 2005-VI.

${ }^{63}$ For a detailed analysis, see Tridimas 2006, Chap. 6 and Groussot 2006, pp. 202-212.

${ }^{64}$ Case T-324/05 Estonia v. Commission [2009] ECR II-03681; Case C-535/09 P Estonia v. Commission [2011] ECLI:EU:C:2011:171.

${ }^{65}$ Czech Constitutional Court, Pl. ÚS 50/04 (Sugar Quotas III), 08.03.2006, English translation available at http://www.usoud.cz.
} 
even to significant limitation'. The Court concluded that its own previous judgments had been 'excessive' and emphasised the need for the Court itself to apply 'constitutional self-restraint'.

In the Netherlands, with regard to legitimate expectations in the field of state aid, it has been commented that the CJEU has adopted 'a much more restrictive approach than is considered reasonable and acceptable by Dutch lawyers and scholars' ${ }^{66}$ However, Dutch case law and practice have been adjusted to EU rules after the CJEU, in response to preliminary ruling questions, clarified that the Dutch version of legitimate expectations should not prevail.

Q 2.6.1 Have the above issues with regard to the standard of protection of property rights, legal certainty, legitimate expectations, non-retroactivity and proportionality arisen in the relevant Member State in relation to EU measures? (Note that this question does not concern areas where Member States' measures may have interfered with economic freedoms or other rights arising from EU law. In this area it is well established that the EU Courts apply a stricter test to proportionality as well as to the other general principles of law, and frequently find national measures to be disproportionately restrictive.) $)^{67}$

\subsection{The ESM Treaty, Austerity Programmes and the Democratic, Rule-of-Law-Based State}

Under the ESM Treaty, Member States may be required to contribute funds to the ESM that in several countries potentially amount to a third of the annual state budget (e.g. in Estonia and Ireland). The use of such funds is not subject to democratic control or judicial review, and the $85 \%$ majority rule means that smaller states have no say over the use of the funds. These issues have prompted constitutional challenges in several Member States, but have been found to be compatible with the Treaties by the CJEU. ${ }^{68}$

Q 2.7.1 Has the issue of the constitutionality of the ESM Treaty been raised in the relevant Member State? In particular, the Experts are invited to comment on the following issues:

(a) If the maximum capital calls allowed under the ESM Treaty were to be made, what would be the percentage of the annual state budget and the annual GDP that the calls would represent? In Estonia, in his legal challenge to the Estonian Supreme Court, the Chancellor of Justice pointed out that the unprecedented magnitude of the financial commitment has the potential to seriously limit the very ability of the

\footnotetext{
${ }^{66}$ Claes and Gerards 2012, p. 643, with references to relevant legal commentary.

${ }^{67}$ Chalmers et al. 2006, pp. 450-451. See also Coppel and O'Neill 1992, p. 670 et seq.

${ }^{68}$ Case C-370/12 Pringle [2012] ECLI:EU:C:2012:756.
} 
state to ensure the functioning of state institutions, including the judicial system, and the protection of the rights and social welfare benefits envisaged under the Constitution. ${ }^{69}$ Has the constitutionality of a budgetary commitment of such magnitude been raised as an issue in the relevant Member State?

(b) In Germany, the applicants to the Constitutional Court in the ESM case in that country were concerned about the state taking 'incalculable risks', with Parliament no longer being able to exercise overall budgetary responsibility. ${ }^{70}$ The uncertainty about the existence of a maximum limit was also raised in the Estonian case. The German Constitutional Court noted the ambiguities in the Treaty's wording regarding whether a maximum limit exists, and thus requested that the Bundestag address this issue in the ratification process. Has the issue of uncertainty about a maximum limit arisen in the relevant Member State? If so, have the courts or Parliament clarified this issue, e.g. in the process of ratification?

(c) Under Arts. 8(4) and 9(3) of the ESM Treaty, the capital calls have to be met 'irrevocably and unconditionally' within seven days. How has this type of unconditional and irreversible commitment been interpreted from the point of view of the Constitution?

Q 2.7.2 Has there been discussion about the constitutionality of other proposed measures, such as Eurobonds and the Banking Union, from the point of view of the potential of exposing the country's citizens and residents to unlimited liability for bank failures in other European countries?

Q 2.7.3 If the Member State has been subject to an EU bailout and a subsequent austerity programme, have constitutional issues arisen with regard to democratic control, the rule of law, transparency, the balancing of the rights of citizens/ residents with those of the international creditor community or other aspects of the bailout programme?

For example, in Portugal, the state budget for the year 2012, which was prepared by the Government to reflect the requirements of the Financial Assistance Programme agreed between Portugal, the European Commission and the IMF, suspended certain benefits for employees of the public sector. The relevant provisions were contested by a group of parliamentarians before the Constitutional Court, invoking the protection of legitimate expectations, the principles of equality and proportionality and the constitutional right to social security. The Constitutional Court declared the relevant provisions unconstitutional, ${ }^{71}$ ruling that the need to tackle the extremely serious economic situation cannot serve as grounds for dispensing the legislator from being subject to the fundamental rights and key

\footnotetext{
${ }^{69}$ Supreme Court of Estonia, Case No. 3-4-1-6-12 on the ESM Treaty, Judgment of 12.07.2012, English translation available at http://www.riigikohus.ee/?id=1347.

${ }^{70}$ German Federal Constitutional Court, Judgment of 12.9.2012, 2 BvR 1390/12, http://www. bverfg.de/entscheidungen/rs20120912_2bvr139012en.html.

${ }^{71}$ See the summary of the judgment in case No. 353/12 in English on the website of the Constitutional Tribunal (http://www.tribunalconstitucional.pt/tc/en/acordaos/20120353s.html).
} 
structural principles of a state based on the rule of law, including the principle of proportional equality. While the Constitution cannot distance itself from economic and financial reality, it does possess, according to the Court, a specific normative autonomy that prevents economic or financial objectives from prevailing in an unlimited way over constitutional rights such as equality.

\subsection{Judicial Review of EU Measures: Access to Justice and the Standard of Review}

It is widely acknowledged that direct access to the EU Courts to challenge the validity of EU measures is very limited, with the expectation of the CJEU being that private parties can make recourse to indirect judicial review via the national courts.

Q 2.8.1 In order to gauge the availability of indirect judicial review in practice, please provide statistical data on the following:

(a) In how many cases in the relevant Member State have applicants requested a preliminary ruling with regard to the validity of an EU measure since 2001? Please provide a brief summary of the type of EU measure contested and the grounds for the alleged invalidity.

(b) In how many of such cases since 2006 did the national court send a preliminary ruling request to the CJEU with regard to the validity of an EU measure? What type of measure was contested and on what grounds? Please note that while data from 2001-2005 on preliminary references regarding validity is available in a study by Takis Tridimas and Gabriel Gari, ${ }^{72}$ Experts are welcome to comment on the constitutional issues raised by the relevant cases.

(c) How many preliminary ruling references since 2006 have led to a partial or full annulment of the relevant EU measure? Please specify whether the measure challenged was a decision, directive or regulation, and the grounds for annulment.

Q 2.8.2 Turning to the standard of review, British scholars have pointed to a 'notable' contrast between proceedings before the domestic courts against national authorities and in proceedings before the European Courts against EU institutions in matters of economic regulation. ${ }^{73}$ One judge of the ECtHR has questioned the neutrality of the EU Courts, pointing out that the public interest of the European Union makes it 'rather difficult for the ECJ to find violations' of the general principles of law. ${ }^{74}$ Six other ECtHR judges have cautioned against the emergence of 'double standards', noting that in the case law of the ECtHR, EU Member States

\footnotetext{
72 Tridimas and Gari 2010, p. 166 et seq.

${ }^{73}$ For relevant case law, see Chalmers et al. 2006, pp. 436-437.

${ }^{74}$ European Court of Human Rights, Concurring Opinion of Judge Ress in Bosphorus Hava Yollarl Turizm ve Ticaret Anonim Şirketi v. Ireland [GC], no. 45036/98, ECHR 2005-VI.
} 
'live under a ... more lenient system' as regards the protection of ECHR rights in areas where they implement EU law. ${ }^{75}$

A statistical study regarding annulments by EU courts in $2001-2005^{76}$ shows that approximately $6.4 \%$ of challenges against measures of general application (directives and regulations) led to annulment in the General Court. It is likely that the success rate in the Court of Justice of challenges brought by the Member States and private parties is broadly at a similar level: the higher overall success rate of $16.1 \%$ in the Court of Justice includes the high rate of success $(75 \%)$ of actions initiated by the EU institutions, compared to the $26.4 \%$ success rate of actions initiated by the Member States. The success rate was approximately 35\% against decisions of the European Commission in both Courts. The annulment in most cases resulted from non-compliance with the parent EU legislation (review of administrative rule-making rather than review of constitutionality). In most cases the annulment occurred on procedural grounds (especially exceeding delegated powers), with some cases leading to success on the basis of general principles such as proportionality and legitimate expectations. The study notes that fundamental rights grounds did not feature prominently and did not bring success in cases against Union institutions. Note that $\mathrm{Kadi}^{77}$ and $S c h e c k e^{78}$ were decided after the time period studied.

Is the standard of judicial review by the EU Courts considered lower than that in the relevant Member State? What is the Expert's view on this matter? If the standard is deemed lower, is this regarded as justified in view of the objectives sought? Is the standard of review tenable in the long term, given the expansion of EU powers beyond the single market? Given that the CJEU is setting the standards for 28 Member States through the supremacy of EU law, might a case be made for a stricter standard of judicial review of EU measures? ${ }^{79}$

Q 2.8.3 Do the constitutional court, the supreme court and/or other courts overall take a vigorous or a deferential approach to the review of constitutionality/legality of legislation, regulatory acts of the executive branch and administrative action? In systems where the national parliament or its bodies (e.g. the Constitutional Law Committee of the Finnish Parliament) play an important role in ensuring the conformity of legislation with the Constitution, please include them in the account accordingly. If possible, please corroborate the description with a brief summary of statistical data on the proportion of validity challenges concerning domestic (non-EU-related) acts leading to annulment and the main grounds for annulment.

\footnotetext{
${ }^{75}$ European Court of Human Rights, Concurring Opinion of Judge Ress, and Joint Concurring Opinion of Judges Rozakis, Tulkens, Traja, Botoucharova, Zagrebelsky and Garlicki in Bosphorus Hava Yollarl Turizm ve Ticaret Anonim Sirketi v. Ireland [GC], no. 45036/98, ECHR 2005-VI.

76 Tridimas and Gari 2010, summary of conclusions at p. 170 et seq.

77 Joined cases C-402/05 P and C-415/05 P Kadi and Al Barakaat International Foundation v. Council and Commission, supra n. 60.

${ }^{78}$ Joined cases C-92/09 and C-93/09 Volker und Markus Schecke and Eifert [2010] ECR I-11063.

${ }^{79}$ For this argument, see Albi 2015b, p. 334.
} 
Q 2.8.4 To what extent does the national constitutional court or supreme court review measures that implement EU legislation (a) in terms of its doctrinal statement; (b) in practice in actual judgments? Has the constitutional court or supreme court adopted a position similar to the German Constitutional Court's Solange II judgment $^{80}$ or the ECtHR's Bosphorus judgment, ${ }^{81}$ which assumes that the EU standard of protection of rights is equivalent to the national or ECtHR standard, unless the applicant proves a manifest deficiency?

Q 2.8.5 If the standard of review by the CJEU is regarded as lower than in the relevant Member State and the national constitutional court or supreme court does not, in practice, review measures implementing EU law or assumes the equivalence of the standards of protection, has any concern been expressed about a resulting gap in judicial review? What is the Expert's view on this matter? In the context of EU accession to the ECHR, a concern about a potential gap has been noted in the General Report of the FIDE 2012 Congress Reports Volume 1, which points out that the Bosphorus doctrine

effectively shields governments acting within the EU framework from scrutiny. This effect of shielding is even stronger, if it is not only the ECtHR that presumes EU compliance with the ECHR, but also national courts refrain from scrutinising acts under EU law from compatibility with the ECHR on such a presumption. ${ }^{82}$

Q 2.8.6 In the Advocaten voor de Wereld case, the question of equal treatment of citizens falling under the scope of EU law and falling under the scope of domestic law as regards the interpretation of nulla poena sine lege was raised. Has the broader issue of equal treatment of individuals falling within the scope of EU law and individuals falling within the scope of domestic protection of constitutional rights arisen in the relevant Member State and in the Expert's view?

\subsection{Other Constitutional Rights and Principles}

Q 2.9.1 Please comment on any other significant issues that have arisen with regard to constitutional rights or the rule of law in the relevant Member State in relation to EU law.

For example, in some countries, there has been pressure to implement EU requirements that affect individual rights or impose obligations on individuals by a governmental regulation, rather than by a parliamentary statute that requires democratic deliberation, as has traditionally been required by constitutional courts. Implementation by governmental regulation may be seen as a way to increase the

\footnotetext{
${ }^{80}$ German Federal Constitutional Court, Wünsche Handelsgesellschaft (Solange II), (1987) CMLR 225.

${ }^{81}$ Bosphorus Hava Yollar Turizm ve Ticaret Anonim Şirketi v. Ireland [GC], no. 45036/98, ECHR 2005-VI.

${ }^{82}$ Besselink 2012, p. 120, references omitted.
} 
speed of implementation, as well as the state's ranking on the European Commission's scoreboard. This issue also arose in the Hungarian Sugar case, ${ }^{83}$ where the relevant national Act had delegated the adoption of the rules defining the subjects liable to pay a charge and the method of determining the charge to the executive. This was found to be in breach of the constitutional requirement that fundamental rights and duties be exclusively determined by a parliamentary statute.

In Ireland, the introduction of indictable offences by a governmental instrument was prohibited; however, this rule was abolished in order to facilitate implementation of obligations necessitated by EU membership. ${ }^{84}$ Have the above issues arisen in the relevant Member State?

\subsection{Common Constitutional Traditions}

While 'common constitutional traditions' have formally provided a source of inspiration for the CJEU in identifying the rights protected by EU law, the General Report of the FIDE 2012 Congress Reports Volume 1 on fundamental rights notes that they have not functioned as an important direct source of protection in the case law of the CJEU. ${ }^{85}$ The General Report goes on to remark:

The accent has not been on national traditions but on the European fundamental rights
sources. National constitutional traditions are hardly ever referred to except in a most per-
functory manner. They do not play a role that is comparable to that of legal and social
developments in the framework of the 'common ground' or 'consensual' approach of the
ECtHR.... In a sense, there has been a shift away from the national to the European context.

Q 2.10.1 The questionnaire for Volume 1 of the FIDE 2012 Congress Reports posed a question to the national rapporteurs on the role of the common and individual constitutional traditions at present and in future. ${ }^{87}$ While this did not lead to significant reflection by the Volume's respondents, the present Questionnaire invites the Experts to further consider this area. What is the Expert's view on which rights and values might form part of the 'common constitutional traditions'?

Could any of the constitutional rights and principles addressed in this Questionnaire be regarded as part of the 'common constitutional traditions', e.g. the principle of nulla poena sine lege, the right to judicial protection, etc.? The German Constitutional Court has noted in the Data Retention case cited in Sect. 2.4 that it is part of Germany's constitutional identity that the citizens' enjoyment of freedom may not be totally recorded and registered. Is this something that could perhaps be

\footnotetext{
${ }^{83}$ Decision 17/2004 (V. 25) AB.

${ }^{84}$ See for relevant case law Barrett 2013, pp. 154-155.

${ }^{85}$ Besselink 2012, question 14 at p. 16.

${ }^{86}$ Besselink 2012, pp. 137-138.

${ }^{87}$ Besselink 2012, question 14 at p. 16.
} 
regarded as a 'common constitutional tradition', rather than as an idiosyncratic element of German constitutional identity?

Q 2.10.2 The Experts are also invited to reflect on whether there might be practical mechanisms for rendering the 'common constitutional traditions' a more direct and relevant source in EU law. For example, at present, when national courts send preliminary ruling references to the European Court of Justice, the courts typically refer to the relevant EU and ECHR provisions. Might there be merit in also highlighting the long-standing constitutional rights or safeguards for the rule of law in the national constitution, along with comparative case law on the established standards in different Member States? ${ }^{88}$

\subsection{Article 53 of the Charter and the Issue of Stricter Constitutional Standards}

Article 53 of the EU Charter of Fundamental Rights (Charter) provides: 'Nothing in this Charter shall be interpreted as restricting or adversely affecting human rights and fundamental freedoms as recognised, in their respective fields of application, by ... the Member States' constitutions.'

A question on the permissibility of using this provision to retain a higher level of protection under the national constitution was posed to the CJEU by the Spanish Constitutional Court in the above-mentioned Melloni case. The Spanish Constitutional Court noted in its preliminary ruling request that the protection of rights in EU law is autonomous, and that Arts. 47 and 48 of the EU Charter of Fundamental Rights protect a fair, public hearing and the right to be defended and represented. The Constitutional Court referred to the Explanations to the Charter, ${ }^{89}$ according to which Arts. 47 and 48 are based upon Art. 6 ECHR on fair trial. To this end, the Spanish Constitutional Court noted that the ECHR only provides a minimum floor of protection, while states may grant more extensive protection (Art. 53 ECHR). It went on to note that the level of protection given by the Spanish Constitution, according to the Constitutional Court's interpretation, is higher than the protection afforded by the ECHR and the EAW Framework Decision. Based on the above, the Spanish Constitutional Court asked whether it could invoke Art. 53 of the Charter to provide a higher level of protection under the national constitution, should the CJEU not find Art. 4a of EAW Framework Decision to be invalid. The CJEU upheld the legality of the measure, and rejected the possibility of granting a higher level of protection under the Constitution, on the grounds that

casting doubt on the uniformity of the standard of protection of fundamental rights as defined in ... [the EAW] framework decision, would undermine the principles of mutual

\footnotetext{
${ }^{88}$ For a call to this end, see e.g. Torres Pérez 2009, p. 134 et seq., and Albi 2015b, pp. 330-331.

${ }^{89}$ Explanations Relating to the Charter of Fundamental Rights, [2007] OJ C 303/17.
} 
trust and recognition which that decision purports to uphold and would, therefore, compromise the efficacy of that framework decision. ${ }^{90}$

Prior to the Melloni judgment, the national rapporteurs of Germany, Austria, Hungary, Italy, Portugal, Spain and Bulgaria for the FIDE 2012 Congress Reports, Volume 1, assumed that under Art. 53 of the Charter, the national standard of protection would prevail if higher. ${ }^{91}$ Aida Torres Pérez has developed a compelling and comprehensively researched argument in support of allowing a stricter standard of protection under national constitutions based on Art. 53 of the EU Charter, along with a greater degree of deference to national constitutional courts. ${ }^{92}$

Q 2.11.1 It is common ground that in a significant range of areas and cases, the ECHR has played an important role in increasing the standard of protection of rights in the Member States. However, at the same time, the ECHR sets the minimum floor of protection for 47 countries, and thus at times the national constitutional standard may be higher. Has there been a discussion in the relevant Member State on whether it is justified for the Court of Justice to set the standard of protection for Charter rights at the level of the ECHR, or whether there are areas where there may be a case for increasing the standard to match the level provided under the national constitutions by constitutional courts and/or supreme courts? Additionally, might there be a case for allowing higher standards at national level, along with greater deference to national constitutional courts/supreme courts? What is the Expert's view on this matter?

\subsection{Democratic Debate on Constitutional Rights and Values}

Q 2.12.1 Fair Trials International has noted that the adoption of the European Arrest Warrant Framework Decision was marked by 'the lack of public engagement in the area of defence rights and the almost total absence of political debate on the subject'. ${ }^{93}$ In the Expert's observation, was there a public deliberation on constitutional rights in the relevant Member State, at the time of the adoption (or, if not, at the time of the national implementation) of (a) the European Arrest Warrant Framework Decision; and (b) the EU Data Retention Directive?

Q 2.12.2 The European Court of Justice ordered Sweden to pay a fine of 3 million EUR for delays in the national implementation of the Data Retention Directive. The CJEU dismissed Sweden's argument that the delays were due to the need

\footnotetext{
${ }^{90}$ Case C-399/11 Melloni, supra n. 36, paras. 59 and 63.

${ }^{91}$ Besselink 2012, p. 133 and footnote 177.

92 See Torres Pérez 2009, pp. 62 et seq., 92, 162.

${ }^{93}$ Fair Trials International submission to the EU Justice and Home Affairs Council Working Group, 9 July 2009, http://www.fairtrials.net/campaigns, p. 4.
} 
to respond to an extensive political debate concerning the transposition of Directive 2006/24 into domestic law and that the implementation of the measures required to effect that transposition has led to problems at the legislative procedural level and to difficult choices involving weighing the protection of privacy against the need to combat crime effectively... . ${ }^{94}$

The European Commission brought a further enforcement action against Germany, with a fine of 300,000 EUR per day. ${ }^{95}$ The Commission rejected the German Government's argument that the delay had resulted from the Constitutional Court's judgment declaring the transposition measures unconstitutional and void.

In the Expert's analysis, when important constitutional issues have arisen and have been referred to the constitutional court at the stage of implementing EU law, does the present system allow sufficient space for democratic deliberation, constitutional review and accommodation of important constitutional issues? Please also note the restricted standing of private parties to request judicial review of EU legislative measures and the low level of annulment of legislative measures by the CJEU (see Sect. 2.8).

Q 2.12.3 Would the Expert support a recommendation to suspend the application and carry out a review of EU measures, where important constitutional issues have been identified by a number of constitutional courts?

Would the Expert support a recommendation to recognise as a legitimate defence on the part of a Member State in an infringement proceeding that unconstitutionality has been identified in accordance with the domestic system of control of constitutionality $?^{96}$

\subsection{Experts' Analysis on the Protection of Constitutional Rights in EU Law}

Q 2.13.1 Does the Expert share the concerns about an overall reduction in the standard of protection of constitutional rights and the rule of law in the context of EU law (except in the areas where the rights arise from EU law, such as free movement, non-discrimination, gender equality and other areas noted in the Introduction to Part 2, or where the rights are enforced vis-à-vis the Member States rather than the EU institutions)?

Q 2.13.2 If the answer to the previous question is 'yes', please answer the following questions.

\footnotetext{
94 Case C-270/11 Commission v. Sweden [2013] ECLI:EU:C:2013:339.

${ }^{95}$ Case C-329/12 Commission v. Germany [2014] ECLI:EU:C:2014:2034; see European Commission Press Release, Data retention: Commission takes Germany to Court requesting that fines be imposed, IP/12/530 (31 May 2012), http://europa.eu/rapid/press-release_IP-12-530_en. htm.

${ }^{96}$ The Principal Investigator is grateful to Samo Bardutzky for this question regarding recognition of constitutional defences.
} 
Has the reduction in the standard of protection of constitutional rights been significant or limited in extent in the Expert's view? Has the reduction been justified and proportionate in view of the overall objectives sought?

Is such reduction inevitable given the objectives of European integration, or has it rather resulted from a lack of wider awareness and debate given issues such as the complexity of multilevel governance? If the reduction of standards is deemed inevitable for the time being given the objectives sought, should the standard be restored in the future when such objectives are achieved, or should such standard remain in place on a continuous basis?

If the reduction is not considered inevitable, what does the Expert consider to be the main ways for upholding and enhancing the protection of constitutional rights? For example,

- EU accession to the ECHR (however, please comment how issues such as increased complexity and the ECHR providing a minimum floor of protection would be addressed);

- A revised approach and enhanced responsiveness by the EU Courts (see question 2.13.3);

- A more proactive role for national constitutional courts and/or supreme courts in highlighting the issues surrounding the standard of protection of constitutional rights in European judicial dialogues; ${ }^{97}$

- A more proactive role for other national institutions, such as national parliaments and ombudsmen, in highlighting constitutional issues in European governance;

- Allowing a stricter standard of protection under national constitutions on the basis of Art. 53 of the EU Charter of Fundamental Rights, and a greater degree of deference to national constitutional courts (see Sect. 2.11);

- Creation of a new independent judicial body, e.g. the European Constitutional Tribunal (with ex ante or ex post review); ${ }^{98}$

- Comments and other solutions.

Q 2.13.3 With regard to the Advocaten voor de Wereld case regarding nulla poena sine lege, concern has been expressed that the European Court of Justice 'refused to make any comment on much-contested issues' and made 'little effort to engage with ...[its] national counterparts'. ${ }^{99}$ Other authors have called upon the Court to 'abandon the cryptic, Cartesian style', which is 'not conducive to a good conversation with national courts', ${ }^{100}$ and have noted that 'it is crucial that the Court display in its judgments that national sensibilities were fully considered and taken into account'. ${ }^{101}$

\footnotetext{
${ }^{97}$ For a call to this end, see e.g. Torres Pérez 2009, p. 134 et seq., and Albi 2015b, pp. 330-331.

${ }^{98}$ Calls to this effect have been put forward by J.H.H. Weiler, R. Herzog and others.

${ }^{99}$ Sarmiento 2008, pp. 177-178.

${ }^{100}$ Weiler 2001, p. 225.

${ }^{101}$ Ibid.
} 
What is the Expert's assessment on the responsiveness of the European Court of Justice with regard to national constitutional concerns? Have constitutional issues been raised by a national court in the relevant Member State in a preliminary ruling request to the CJEU? If so, has the CJEU's judgment been seen as adequately responding to the issue and/or taking the concern sufficiently into account?

If the Expert regards a revised approach by the CJEU as a key solution, please comment on specific potential changes. For example, scholars have recommended revising the autonomous, self-referential interpretation of rights on the part of the CJEU by making systematic use of comparative method in determining the protection of constitutional rights; ${ }^{102}$ making the arguments of the parties and of the intervening governments fully available on the Court's website; ${ }^{103}$ a stricter standard of judicial review of EU measures (see Sect. 2.8); and allowing dissenting opinions.

Q 2.13.4 If the Expert sees solutions in a more proactive contribution at the national level, the Expert is welcome to formulate potential constitutional amendment proposals or other regulatory changes that would e.g. mandate a more proactive approach to upholding and shaping constitutional rights, the rule of law, democracy and other substantive constitutional values on the part of national parliaments, courts and other institutions in the context of European governance.

\section{Constitutional Issues in Global Governance}

Introduction The third section of the Questionnaire explores the more recent phenomenon of global governance, which, besides the extensive shift of powers to a multiplicity of international organisations and global institutions, involves a number of important structural changes. These include the rise of global regulatory networks, ${ }^{104}$ the shift of global law-making outside the conventional formats of public international law to include a significant amount of rule-making by private and professional bodies, ${ }^{105}$ and the wide-spread use of non-binding and non-justiciable yet highly effective soft law. Additionally, the distinction between domestic and international law has increasingly become blurred, as regulators come together in global institutions and set standards that they then implement in their domestic capacity. Indeed, a leading school of scholars regards global governance essentially as 'global administrative law', as regulatory functions are now performed in a global rather than national context. ${ }^{106}$ The consequence of such

\footnotetext{
${ }^{102}$ For a compelling and extensively researched argument to this end, see Torres Pérez, supra n. 88 , pp. 144 et seq.

103 The author is grateful to Giuseppe Martinico for this point.

${ }^{104}$ Slaughter 2004.

105 Teubner 1996, p. 3 et seq.

${ }^{106}$ Krisch and Kingsbury 2006, pp. 1-3 and 11.
} 
developments, as Nico Krisch notes, is that "the role of treaties as "transmission belts", ensuring accountability to states and through the ratification process also to the public within states, has become weaker and weaker'. ${ }^{107}$

While global governance institutions and networks play a vital role in advancing peaceful co-operation, human rights and democracy, the literature in the field increasingly also highlights important challenges to constitutionalism. ${ }^{108}$ Central among them has been the erosion of democratic oversight. Foreign affairs have traditionally formed the prerogative of the executive, and hence countries are typically represented in transnational institutions and networks by their governments. There is also the broader problem of the legitimacy of the power exercised by global governance institutions. Among further challenges are a lack of accountability, deficiencies in legal protection, the capture of regulatory networks by narrow interest groups and a lack of transparency, as decision-makers are not clearly identifiable. ${ }^{109}$ Regarding the rule of law as the primary constitutional principle, Anne Peters has shown how the downsides of globalisation affect all the key elements constituting the rule of law, including the requirement that government action must be bound by the law and has to be transparent, the separation of powers with checks and balances, fundamental rights protection, due process and judicial review of governmental action. ${ }^{110}$ Indeed, Peters concludes that in addition to positive effects, state constitutions have also been invisibly 'globalised' 'in a rather negative way', ${ }^{111}$ and there has been a 'hollowing out' of national constitutions or 'de-constitutionalisation' at the domestic level. ${ }^{112}$

In order to respond to these problems, the global governance discourse is predominantly looking for solutions to enhance democracy and accountability at the transnational level. However, while global solutions are essential, this project invites the Experts to consider whether the above challenges could also be addressed at the national level, with corresponding adjustments in the national constitutional frameworks.

\subsection{Constitutional Rules on International Organisations and the Ratification of Treaties}

Q 3.1.1 Please briefly outline the constitutional or other provisions that regulate the transfer of powers to international organisations and the ratification of treaties. Do

\footnotetext{
${ }^{107}$ Krisch 2006, p. 277.

108 Grimm 2005, p. 458; Peters 2007, p. 260 et seq.; Kiiver 2009.

${ }^{109}$ For different aspects see e.g. Alston 1997, p. 441; Krisch 2006, pp. 247-278; Slaughter 2004; Peters 2007, p. 260 et seq.

${ }^{110}$ Peters 2007, p. 271.

${ }^{111}$ Peters 2007, pp. 254 and 273 et seq. See also Grimm 2005.

${ }^{112}$ See also Peters 2005 and 2006.
} 
the relevant provisions contain references to the objectives sought by international co-operation, limits to the delegation of powers and/or values and principles that ought to be upheld by the state when participating in international co-operation? Are there constitutional provisions with regard to specific international organisations or institutions, such as NATO or the International Criminal Court?

Q 3.1.2 If any of the relevant provisions have been introduced since 1990, please outline the aims of the amendment, the amendment process and the conceptual background to the choice of wording. What drove the reform, which obstacles were encountered, which key factors influenced the decisions on the scope and content of the amendment? To what extent was the advice of scholars and experts followed by political decision-makers?

Q 3.1.3 Have any provisions been highlighted as being in need of amendment (e.g. in court decisions, by parliamentary or governmental bodies or in legal commentary), with regard to international law and global governance, especially as regards the question of how constitutional texts could better respond to the transfer of powers to transnational level and more effectively uphold constitutional values in international co-operation? Please also include any attempts at constitutional reform in this field that have not materialised in practice.

Q 3.1.4 Further to Question 1.5.3 in Part 1, please add any additional observations or recommendations regarding the role of the national constitution in the context of international law and global governance, and whether there is a need for amendments in this context. Please outline the potential areas and tentative content of the amendments.

If the Expert sees a solution in a more proactive contribution at the national level, the Expert is welcome to formulate potential amendment proposals or other regulatory changes, which would e.g. mandate a more proactive approach to upholding and shaping democracy, the rule of law, constitutional rights and substantive constitutional values, on the part of national parliaments, courts and other institutions in the context of global governance.

\subsection{The Position of International Law in National Law}

Q 3.2.1 Please briefly outline the constitutional or other rules governing the application of treaties and their position in domestic law.

Q 3.2.2 It has been commented that neither dualism nor monism in their traditional form are able to capture the diversity of the processes of globalisation. ${ }^{113}$ Please outline the legal commentary on the applicability of monism and dualism in the relevant Member State. What is the Expert's view on the continued relevance of the above concepts?

${ }^{113}$ Nollkaemper 2007, p. 11; Von Bogdandy 2008, pp. 399-400. 


\subsection{Democratic Control}

Existing constitutional provisions typically concern the initial formal ratification by parliaments of international agreements or of accession to international organisations. Some scholars have noted the need for extended parliamentary participation in the international negotiation process and prior to the conclusion of a treaty. ${ }^{114}$ Others have called for continued involvement of national parliaments or their networks with regard to the international organisations beyond the initial conclusion of a treaty, especially in the case of the World Trade Organisation. ${ }^{15}$ Yet in Europe, the Swiss Parliament is the only legislature to systematically oversee WTO and transnational rules that affect national legislation. The Swiss Constitution was amended to this end in 1992 and further in 1999, to provide that the Federal Assembly shall participate in the shaping of foreign policy and supervise foreign relations (Art. 166).

More effective involvement of parliaments may also be necessary at the stage of implementing international commitments, as shown by a case in Latvia's Constitutional Court, where 9,000 pensioners challenged the constitutionality of a law that reduced their pensions by up to $70 \%$ in order to implement an IMF package. The Court noted that the measure had been adopted in a rush, without consultations, and that the IMF package had been very hard for the Court to access. To balance the social impact of the measures in a fairer way, the Latvian Constitutional Court ruled that the contested law was in breach of legitimate expectations, and that the Government must repay the pension reductions in later years when the economy improves. ${ }^{116}$

Q 3.3.1 Please briefly outline the constitutional and other rules on parliamentary involvement with regard to (a) the initial negotiation and ratification of an accession treaty; and (b) subsequent involvement in scrutinising an international organisation beyond initial ratification of the membership treaty. Are there any aspects in the parliamentary involvement in the relevant Member State that could be regarded as a best practice and could be recommended more widely? If relevant studies are available, please include a summary indicating to what extent the national parliament typically holds a debate on substantive matters arising from international obligations, beyond a formal reference to the requirement to transpose international commitments.

Q 3.3.2 Have any international organisations or treaties been subject to a referendum? If so, what has been the rationale for this procedure, e.g. to enhance legitimacy? Some constitutions contain a ban on referendums on treaties. Please indicate whether this rule applies in the relevant Member State.

\footnotetext{
${ }^{114}$ Peters 2007, p. 283, citing Harrington 2006, pp. 121-160.

115 E.g. Maurer et al. 2005, p. 6 et seq. On the need to ensure parliamentary participation in supranational bargaining, see also Grimm 2005, p. 9.

${ }^{116}$ Latvian Constitutional Court, Case No. 2009-43-01, English translation available at: http:// www.satv.tiesa.gov.lv/upload/Judgment\%202009-43.htm.
} 


\subsection{Judicial Review}

Under the classic rule of pacta sunt servanda, it has come to be a standard expectation that national courts ought not to undermine the commitments of the state under international treaties. The acts of international organisations themselves are normally not challengeable in courts and tribunals. However, given the sheer scope of issues for which decision-making has shifted to the global level, views are increasingly expressed that under certain circumstances there should be a right of review of acts of global institutions, especially if they directly affect individuals. ${ }^{117}$ The need for such review was particularly propelled into the spotlight by the widely debated Kadi case. ${ }^{118}$ This concerned UN Security Council resolutions under which the assets of terrorist suspects were frozen without any reasons provided to them or any avenues available for judicial review. The severity of the breach of fundamental rights led to the annulment of the relevant EU measures by the European Court of Justice.

The experience with the Kadi case led Armin von Bogdandy to comment that ' $[t]$ here should always be the possibility ... to limit, legally, the effect of a norm or an act under international law within the domestic legal order if it severely conflicts with constitutional principles. This corresponds to the state of development of international law and the sometimes debatable legitimacy of international legal acts ...119

Q 3.4.1 What are the relevant rules in the Member State in question? To what extent do courts review, in doctrine and in practice, treaties and measures adopted under international law? Please include case law and constitutional issues arising from parliamentary debates or scholarly commentary. How has judicial review been reconciled with the classic rule of pacta sunt servanda? What is the Expert's view on this matter?

\subsection{The Social Welfare Dimension of the Constitution}

The global governance discourse contains a significant volume of literature that is critical of the erosion of the social state and the ever-increasing wealth gap. This is often attributed to the agenda of global economic institutions, which have pushed for liberalisation, deregulation, privatisation of public utilities and other policies representing a belief in the efficiency of unfettered markets. ${ }^{120}$ Serious questions

\footnotetext{
${ }^{117}$ Peters 2007, p. 273, referring to other publications including Cottier and Hertig 2003, pp. 326327. See also Krisch and Kingsbury 2006, p. 11 and Kiiver 2009, p. 9.

${ }^{118}$ Court of Justice, Joined cases C-402/05 P and C-415/05 P, Kadi and Al Barakaat International Foundation v. Council and Commission, supra n. 60.

${ }^{119}$ Von Bogdandy 2008, p. 412.

${ }^{120}$ See e.g. Stiglitz 2002, pp. 442-443.
} 
have also been asked about the mode of rule-making in these organisations. A former Chief Economist at the World Bank, Joseph Stiglitz, has described the IMF as 'the least transparent' institution that he has encountered in public life. ${ }^{121}$ In any event, the policies of international financial institutions, as Alston notes, have resulted in a dramatically reduced ability for a state to carry out the role of counter-balance, watchdog, regulator and the guarantor of the proverbial fair playing field. ${ }^{122}$ In the context of national constitutions, the erosion of the social element, which has been regarded as traditional to European constitutionalism, has been explored by Anne Peters. ${ }^{123}$

Q 3.5.1 If the above issues have been of significance in the case law or the constitutional discourse in the relevant Member State, or raise issues in the Expert's view, please include a summary in this section.

Q 3.5.2 If the country has been subject to a bailout and austerity programme (which has not already been covered in Sect. 2.7.3), please include in this section any issues that may have arisen with regard to IMF/World Bank conditionality in terms of democratic control, transparency, accountability and/or balancing the constitutional rights and social welfare of the citizens and residents against the interests of the international creditor community.

\subsection{Constitutional Rights and Values in Selected Areas of Global Governance}

Q 3.6.1 Please report in this section on any further cases, parliamentary debates and scholarly commentary in areas where constitutional rights, the rule of law, judicial review, democratic control or accountability may have been affected to a significant degree in the context of global governance in the relevant Member State. Some examples may include inclusion in terrorist blacklists, freezing of bank accounts, arrests under anti-terrorist legislation; cases regarding arrest warrants under international agreements and arrest warrants by Interpol; rendition flights and secret prisons. [Editor's note: we did not initially include concerns about the Transatlantic Trade and Investment Partnership (TTIP), due the extensive scope of the Questionnaire. However, given that the TTIP subsequently received heightened public attention, which included a European Citizens' Initiative with 3 million signatures, we informally asked the Experts to report national debates on the TTIP where relevant.] We would also welcome the Expert's analysis of constitutional issues arising in the context of constitutional rights and values in global governance.

\footnotetext{
121 Stiglitz 2002, p. xii.

122 Alston 1997, pp. 442-443.

123 Peters 2007, p. 285 et seq.
} 


\section{References}

Albi A. (2005) EU Enlargement and the Constitutions of Central and Eastern Europe. Cambridge University Press, Cambridge.

Albi A. (2010) From the Banana Saga to a Sugar Saga and Beyond: Could the Post-Communist Constitutional Courts Teach the EU a Lesson in the Rule of Law? CML Rev. 47(3):791-829.

Albi A. (2011) On secret legislation, blanket data recording, arrest warrants and property rights: Questions on the rule of law and judicial review in the EU in the light of post-communist constitutions. In: Popelier P., Van De Heyning C., Van Nuffel P. (eds.) Human Rights Protection in the European Legal Order: The Interaction between the European and the National Courts. Intersentia, Cambridge, pp. 173-210.

Albi A. (2015a) Erosion of Constitutional Rights in EU Law: A Call for 'Substantive Co-operative Constitutionalism' (Part 1). Vienna Journal of International Constitutional Law 9(2):151-185. Available open access at: http://ssrn.com/author=1246144.

Albi A. (2015b) Erosion of Constitutional Rights in EU Law: A Call for 'Substantive Co-operative Constitutionalism' (Part 2). Vienna Journal of International Constitutional Law 9(3):291-343. Available open access at: http://ssrn.com/author=1246144.

Alegre S., Leaf M. (2004) Judicial Cooperation: A Step Too Far Too Soon? Case Study - The European Arrest Warrant. ELJ 10:200-217.

Alston P. (1997) The Myopia of the Handmaidens: International Lawyers and Globalization. EJIL $8: 435$ et seq.

Barrett G. (2013) The Evolving Door to Europe: Reflections on an Eventful Forty Years of Article 29.4 of the Irish Constitution. Irish Jurist 132:154 et seq.

Besselink L. (2006) The Dutch Constitution, the European Constitution and the Referendum in the Netherlands. In Albi A., Ziller J. (eds.) The European Constitution and National Constitutions: Ratification and Beyond. Kluwer, Alphen aan den Rijn, pp. 113-123.

Besselink L. (2012) Questionnaire. In: Laffranque J. (ed.) The Protection of Fundamental Rights Post-Lisbon, Reports of the XXV FIDE Congress Tallinn 2012, Vol. 1. Tartu University Press, Tallinn, pp. 1-18.

Bobek M. (2009) The Binding Force of Babel: The Enforcement of EC Law Unpublished in the Languages of the New Member States. Cambridge Yearbook of European Legal Studies 9:4380.

Carrera S., Guild E., Hernanz N. (2013) Europe's most wanted? Recalibrating Trust in the European Arrest Warrant System. Centre for European Policy Studies Report No. 76, March 2013, p. 16. http://www.ceps.be/ceps/dld/7957/pdf.

Chalmers D., Hadjiemmanuil C., Monti G., Tomkins A. (2006) European Union Law. Cambridge University Press, Cambridge.

Claes M. (2005) Constitutionalizing Europe at its Source: The 'European Clauses' in the National Constitutions: Evolution and Typology. Yearbook of European Law 24(1):81-125.

Claes M., Gerards J. (2012) The Netherlands. In: Laffranque J. (ed.) The Protection of Fundamental Rights Post-Lisbon, Reports of the XXV FIDE Congress Tallinn 2012, Vol. 1. Tartu University Press, Tallinn, pp. 598-613.

Coppel J., O'Neill A. (1992) The European Court of Justice: Taking Rights Seriously? CML Rev. 29(4):669-692.

Cottier T., Hertig M. (2003) The Prospects of 21st Century Constitutionalism. Max Planck Yearbook of United Nations Law 7(1):261-322.

De Witte B. (2001) Constitutional Aspects of European Union Membership in the Original Six Member States: Model Solutions for the Applicant Countries? In: Kellermann A., De Zwaan J., Czuczai J. (eds.) EU Enlargement: The Constitutional Impact at EU and National Level. Asser Press, The Hague, pp. 65-80.

Dobner P., Loughlin M. (2010) Introduction. In: Dobner P., Loughlin M. (eds.) The Twilight of Constitutionalism? OUP, Oxford, pp. xi-xvi. 
Everling, U. (1996) Will Europe Slip on Bananas? The Bananas Judgment of the Court of Justice and National Courts. CML Rev. 33(3):401-437.

Galera S. (2010a) European legal tradition and the EU legal system: understandings and premises about the rule of law's requirements. In: Galera S. (ed.) Judicial Review: A comparative analysis inside the European legal system. Council of Europe Publishing, Strasbourg, pp. 277 300.

Galera, S. (2010b) The European contribution to an emerging global law. In: Galera S. (ed.) Judicial Review: A comparative analysis inside the European legal system. Council of Europe Publishing, Strasbourg, pp. 301-308.

Grimm D. (2005) The Constitution in the Process of Denationalization. Constellations 12(4):447463.

Grimm D. (2010) The Achievement of Constitutionalism and its Prospects in a Changed World. In: Dobner P., Loughlin M. (eds.) The Twilight of Constitutionalism? OUP, Oxford, pp. 3-22.

Groussot X. (2006) General Principles of Community law. Europa Law Publishing, Groningen.

Harlow C. (2006) Global Administrative Law: The Quest for Principles and Values. EJIL 17 (1):187-214.

Harrington, J. (2006) Scrutiny and Approval: The Role for Westminster-style Parliaments in Treaty-Making. International and Comparative Law Quarterly 55(1):121-160.

Herlin-Karnell E. (2010) The integrity of European criminal law co-operation: The nation state, the individual, and the area of freedom, security and justice. In: Amtenbrink F., Van Den Berg P. (eds.) The Constitutional Integrity of the European Union. TMC Asser Press, The Hague, pp. 238 et seq.

Kiernan F., Brittain S., Donnelly C. (2012) Ireland. In: Laffranque J. (ed.) The Protection of Fundamental Rights Post-Lisbon, Reports of the XXV FIDE Congress Tallinn 2012, Vol. 1. Tartu University Press, Tallinn, pp. 561-580.

Kiiver P. (2009) Constitutions in the Age of Internationalisation: Towards Transnational Constitutional Standards (revised version). Concept paper commissioned by the Hague Institute for Internationalisation of Law, http://www.hiil.org.

Krisch N. (2006) The Pluralism of Global Administrative Law. EJIL 17(1):247-278.

Krisch N., Kingsbury R.B. (2006) Introduction: Global Governance and Global Administrative Law in the International Legal Order. EJIL 17(1):1-13.

Laffranque J. (ed.) (2012a) The Protection of Fundamental Rights Post-Lisbon, Reports of the XXV FIDE Congress Tallinn 2012, Vol. 1. Tartu University Press, Tallinn.

Laffranque J. (ed.) (2012b) The Area of Freedom Security and Justice, Including Information Society Issues, Reports of the XXV FIDE Congress Tallinn 2012, Vol. 3. Tartu University Press, Tallinn.

Maurer A., Kietz D., Bendiek A., Parkes R. (2005) Introduction: The Role of Parliaments within the WTO. In: Maurer A. The Role of Parliaments in Scrutinising and Influencing Trade Policy. A Comparative Analysis, Report for the European Parliament. European Parliament, pp. 6 et seq.

Mitsilegas, V. (2012) General Report: The Area of Freedom, Security and Justice from Amsterdam to Lisbon. Challenges of Implementation, Constitutionality and Fundamental Rights. In: Laffranque J. (ed.) The Area of Freedom Security and Justice, Including Information Society Issues, Reports of the XXV FIDE Congress Tallinn 2012, Vol. 3. Tartu University Press, Tallinn, pp. 21-142.

Nollkaemper A. (2007) Introduction. In: Nijman J.E., Nollkaemper A. (eds.) New Perspectives on the Divide Between National and International Law. OUP, Oxford, pp. 11 et seq.

Peters A. (2005) Global Constitutionalism Revisited. International Legal Theory 11:39 et seq.

Peters A. (2006) Compensatory Constitutionalism: The Function and Potential of Fundamental International Norms and Structures. LJIL 19(3):579-610.

Peters A. (2007) The Globalization of State Constitutions. In: Nijman J.E., Nollkaemper A. (eds.) New Perspectives on the Divide Between National and International Law. OUP, Oxford, pp. 260 et seq. 
Rasmussen H. (2006) Denmark's Waning Constitutionalism and Article 20 of the Constitution on Transfer of Sovereignty. In: Albi, A., Ziller J. (eds.) The European Constitution and National Constitutions: Ratification and Beyond. Kluwer, Alphen aan den Rijn, pp. 149-156.

Sajó A. (2004) Accession's Impact on Constitutionalism in the New Member States. In: Bermann G., Pistor K. (eds.) Law and Governance in an Enlarged European Union. Hart, Oxford, pp. 415-436.

Sanger A. (2010) Force of Circumstance: The European Arrest Warrant and Human Rights. Democracy and Security 6:17-51.

Sarmiento D. (2008) European Union: the European arrest warrant and the quest for constitutional coherence. ICON 6(1):171-183.

Slaughter A.M. (2004) A New World Order. Princeton University Press, Princeton.

Stiglitz J. (2002) Globalization and its Discontents. Penguin Books, London.

Storskrubb E., Ziller J. (2007) Access to justice in European comparative law. In: Francioni F. (ed.) Access to Justice as a Human Right. OUP, Oxford, pp. 177-204.

Suksi M. (1993) Bringing in the People: A Comparison of Constitutional Forms and Practices of Referendum. Martinus Nijhoff Publishers, Dordrecht.

Švarc M. (2012) Czech Republic. In: Laffranque J. (ed.) The Area of Freedom Security and Justice, Including Information Society Issues, Reports of the XXV FIDE Congress Tallinn 2012, Vol. 3. Tartu University Press, Tallinn, pp. 261-288.

Teubner G. (1996) Global Bukowina: Legal Pluralism in the World Society. In: Teubner G. (ed.) Global Law Without a State. Dartmouth Publishing, Dartmouth, pp. 3 et seq.

Torres Perez A. (2009) Conflicts of rights in the European Union. A Theory of Supranational Adjudication. OUP, Oxford.

Tridimas T. (2006) The General Principles of EU Law. OUP, Oxford.

Tridimas T., Gari G. (2010) Winners and losers in Luxembourg: A statistical analysis of judicial review before the European Court of Justice and the Court of First Instance (2001-2005). E.L.Rev. 35(2):131-173.

Vitorino A., Leandro Vasconcelos R. (2012) Portugal. In: Laffranque J. (ed.) The Area of Freedom Security and Justice, Including Information Society Issues, Reports of the XXV FIDE Congress Tallinn 2012, Vol. 3. Tartu University Press, Tallinn, pp. 531-554.

Von Bogdandy A. (2008) Pluralism, direct effect, and the ultimate say: On the relationship between international and domestic constitutional law. ICON 6(3-4):397-413.

Weatherill S. (1995) Law and Integration in the European Union. OUP, Oxford.

Weiler J.H.H. (2001) Epilogue: The Judicial Après Nice. In: De Búrca G., Weiler J.H.H. (eds.) The European Court of Justice. OUP, Oxford, pp. 215-226.

Open Access This chapter is licensed under the terms of the Creative Commons Attribution 4.0 International License (http://creativecommons.org/licenses/by/4.0/), which permits use, sharing, adaptation, distribution and reproduction in any medium or format, as long as you give appropriate credit to the original author(s) and the source, provide a link to the Creative Commons license and indicate if changes were made.

The images or other third party material in this chapter are included in the chapter's Creative Commons license, unless indicated otherwise in a credit line to the material. If material is not included in the chapter's Creative Commons license and your intended use is not permitted by statutory regulation or exceeds the permitted use, you will need to obtain permission directly from the copyright holder. 